\title{
Regulation by epidermal growth factor of prostaglandin production and cyclooxygenase activity in sensitized rat endometrial stromal cells in vitro
}

\author{
B. M. Bany and T. G. Kennedy \\ Departments of Physiology and Obstetrics and Gynaecology, University of Western Ontario, London, ON, \\ Canada, N6A 5A5
}

\begin{abstract}
The effect of epidermal growth factor on prostaglandin production and cyclooxygenase activity in endometrial stromal cells isolated from the uteri of ovariectomized rats sensitized for the decidual cell reaction was examined. Treatment with epidermal growth factor $\left(40 \mathrm{ng} \mathrm{ml}^{-1}\right.$ ) for $24 \mathrm{~h}$ caused approximately 6.9-, 3.4-, and 4.1-fold increases in prostaglandin $\mathrm{E}_{2}$, prostaglandin $\mathrm{F}_{2 \alpha}$ and 13,14-dihydro-15-keto-prostaglandin $\mathrm{F}_{2 \alpha}$ accumulation in the media of cultured cells. The increase in prostaglandin $\mathrm{E}_{2}$ accumulation induced by epidermal growth factor was inhibited by $\alpha$-amanitin $\left(2 \mu \mathrm{g} \mathrm{ml}^{-1}\right)$, cycloheximide $\left(0.5 \mu \mathrm{g} \mathrm{ml}{ }^{-1}\right)$ and dexamethasone $\left(5 \mu \mathrm{mol} \mathrm{l^{-1 }}\right)$. Epidermal growth factor increased cyclooxygenase activity in the stromal cells in a time-dependent fashion and this increase in activity was also inhibited by $\alpha$-amanitin, cycloheximide and dexamethasone. These results provide evidence that epidermal growth factor stimulates prostaglandin production in rat endometrial stromal cells from uteri sensitized for the decidual cell reaction through a mechanism that involves an increase in cyclooxygenase activity.
\end{abstract}

\section{Introduction}

The paracrine and autocrine effects of growth factors in the uterus in rodents may be important during implantation (Pollard, 1990). There is indirect evidence in support of this notion for some ligands of the epidermal growth factor (EGF) receptor. EGF, transforming growth factor $\alpha$ (TGF- $\alpha$ ) and heparin-binding EGF, all ligands of the EGF receptor (Prigent and Lemoine, 1992), are expressed in a cell- and time-specific fashion in the uterus during the peri-implantation period (Tamada et al., 1991; Johnson and Chatterjee, 1993a; Das et al., 1994a; Paria et al., 1994). EGF receptors have been localized to all major uterine cell types in immature rats (Lin et al., 1988) and mice (Bossert et al, 1990). However, during the periimplantation period, EGF receptors have been localized to all major uterine cell types except the luminal and glandular epithelia in mice (Das et al., 1994b). Furthermore, the number of EGF receptors appears to increase in the uterus during implantation (Chakraborty et al., 1988; Brown et al., 1989). Thus, there is an increase in the number of EGF-receptors, and three of its ligands are present in the uterus during the peri-implantation period.

There is direct evidence that EGF may play a role in blastocyst implantation. EGF can initiate implantation of embryos transferred into progesterone-primed hypophysectomized rats (Johnson and Chatterjee, 1989a). In rats in which implantation has been delayed by hypophysectomy, EGF can replace oestrogen to induce implantation provided that uterine trauma occurs (Johnson and Chatterjee, 1989b). Therefore, it is

Received 2 November 1994. clear that, under the conditions of these studies, EGF can replace oestrogen in the induction of implantation. However, little is known about the effect of activation of the EGF receptor signalling pathway in the endometrium during implantation.

One possible role for ligands of the EGF receptor during implantation is to modulate prostaglandin (PG) concentrations. Such a role would be important because PGs play an obligatory role in the process of implantation and decidualization in many animals (Kennedy, 1990; Smith, 1991). In support of this possible role is the observation that the inhibitory effect of indomethacin on oestriol-induced implantation can be reversed by EGF in mice in which implantation has been delayed by ovariectomy (Paria et al., 1991). Further, EGF stimulates prostaglandin $\mathrm{E}_{2}\left(\mathrm{PGE}_{2}\right)$ and prostaglandin $\mathrm{F}_{2 \alpha}\left(\mathrm{PGF}_{2 \alpha}\right)$ secretion by endometrial stromal cells isolated from nonpregnant mice (Paria et al., 1991). However, nothing is known about the effect of EGF receptor ligands on PG production by endometrial stromal cells from the peri-implantation uterus or from uteri sensitized for the decidual cell reaction. This study was undertaken to determine the effect of EGF on PG production and cyclooxygenase activity in endometrial stromal cells isolated from rat uteri that were sensitized for the decidual reaction.

\section{Materials and Methods}

\section{Materials}

The following reagents were purchased from GIBCO (Burlington, ON): Hank's balanced salt solution (HBSS) without 


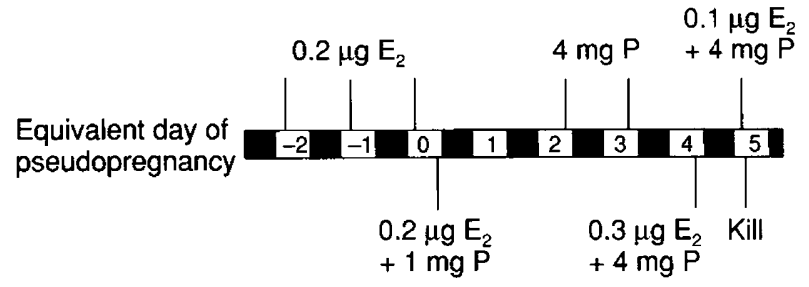

Fig. 1. Schematic representation of the sequence of s.c. hormone administration to ovariectomized rats (oestrogen, $\mathrm{E}_{2} ;$ progesterone, $\mathrm{P}$ ). Dark areas, lights-off; open areas, lights-on. Animals were killed in the moming on the equivalent of day 5 of pseudopregnancy, at which time the uteri were sensitized for decidualization.

$\mathrm{Mg}^{2+}$ or $\mathrm{Ca}^{2+}$, heat-inactivated fetal calf serum, Hepes, pancreatin, penicillin-streptomycin, fungizone, Dulbecco's modified Eagle's medium:F-12 nutrient mixture (DMEM:F12), human recombinant EGF and Dulbecco's phosphate-buffered saline (DPBS). Dispase (neutral protease from Bacillus polymyxa Grade II) was purchased from Mannheim Boehringer Canada (Dorval, QU). Sesame oil, oestradiol, progesterone, cycloheximide, $\alpha$-amanitin, indomethacin, dexamethasone, BSA, collagenase (type-II), SDS and EDTA were purchased from Sigma Chemical Company (St Louis, MO).

$\mathrm{PGE}_{2}, \mathrm{PGF}_{2 \alpha}$ arachidonic acid and 13,14-dihydro-15keto-PGF $2 \alpha$ (PGFM) were purchased from Cayman Chemical Company (Ann Arbor, MI). Antiserum against PGFM was provided by The Upjohn Company (Kalamazoo, MI) and $\left[{ }^{3} \mathrm{H}\right] \mathrm{PGE}_{2},\left[{ }^{3} \mathrm{H}\right] \mathrm{PGF}_{2 \alpha}$ and $\left[{ }^{3} \mathrm{H}\right] \mathrm{PGFM}$ were obtained from Amersham (Oakville, ON).

\section{Animals}

Female Harlan Sprague-Dawley rats $(200-225 \mathrm{~g})$, obtained from Harlan Sprague-Dawley Inc. (Indianapolis, IN), were housed under temperature- and light-controlled conditions (14 $\mathrm{h}$ light:10 $\mathrm{h}$ dark; $12: 00 \mathrm{~h}$ as the midpoint of the light phase) with free access to food and water. The animals were ovariectomized under ether anaesthesia and allowed at least 6 days to recover. Oestradiol and progesterone in sesame oil were administered s.c. (as outlined in Fig. 1) to obtain rats with uteri sensitized for decidualization.

\section{Stromal cell isolation and culture}

On the equivalent of day 5 of pseudopregnancy, the rats were killed by decapitation. Uterine horns were obtained, dissected free from adherent tissue and split longitudinally. Endometrial stromal cells were then isolated by enzymatic dispersion using pancreatin and dispase followed by collagenase as described by Yee and Kennedy (1991). Stromal cells pooled from 5-10 uteri were suspended in DMEM:F12 containing heat-inactivated charcoal-stripped fetal calf serum $(10 \%$, $\mathrm{v} / \mathrm{v})$, penicillin (100 units $\left.\mathrm{ml}^{-1}\right)$, streptomycin $(100 \mu \mathrm{g} \mathrm{ml}-\mathrm{I})$ and fungizone $\left(1.25 \mu \mathrm{g} \mathrm{ml}^{-1}\right)$. The cell suspension was filtered through nylon mesh $(70 \mu \mathrm{m})$ to remove glands and clumps of epithelial cells and plated at $5 \times 10^{5}$ cells (in $0.5 \mathrm{ml}$ culture medium) in 24-well plates (Becton-Dickinson, Lincoln Park, NJ). After an initial incubation period of $2 \mathrm{~h}$ at $37^{\circ} \mathrm{C}$ under $5 \%$
$\mathrm{CO}_{2}: 95 \%$ air to allow differential attachment of the stromal cells, the medium was removed and replaced with serum-free medium. This was defined as $\mathrm{Oh}$ of day 1 of culture. The medium was changed every $24 \mathrm{~h}$.

\section{Measurement of $P G$ accumulation}

Stromal cells were incubated in serum-free DMEM:F12 with or without various treatments for $1.5-24 \mathrm{~h}$ on days $1-3$ of culture. At the end of this incubation period, the medium was collected for measurement of PG concentrations. After washing with DPBS, the cells were solubilized in $1 \mathrm{ml} 1 \%(\mathrm{w} / \mathrm{v})$ SDS-1 mmol EDTA ${ }^{-1}$ and the amount of protein in each well was measured using the method of Lowry et al. (1951) with BSA as a standard. PG content, expressed as $\mathrm{ng} \mathrm{mg}^{-1}$ of protein, was used as a measure of PG accumulation.

\section{Cyclooxygenase activity assay}

Stromal cell cyclooxygenase activity was measured using a method similar to that of Lee et al. (1992). After a 1.5-24 h incubation with various treatments, the media were removed and replaced with fresh media containing saturating concentrations $\left(100 \mu \mathrm{mol} \mathrm{I}^{-1}\right.$, data not shown) of arachidonic acid. After incubation for $10 \mathrm{~min}$ at $37^{\circ} \mathrm{C}$ under $5 \% \mathrm{CO}_{2}: 95 \%$ air, the media were removed for $\mathrm{PGE}_{2}$ measurement and the cells were retained for protein determination. Under these conditions, the amount of $\mathrm{PGE}_{2}$ accumulated in the media reflects its synthesis from the exogenous arachidonic acid, since no PG could be detected in the media of cells incubated without arachidonic acid (data not shown). Furthermore, the amount of $\mathrm{PGE}_{2}$ accumulated in the media was not a consequence of nonenzymatic formation, since no PG could be detected in the media of cells incubated with arachidonic acid plus indomethacin ( $10^{-5} \mathrm{~mol} \mathrm{l}^{-1}$; data not shown). Therefore, as a measure of cyclooxygenase activity, the amount of $\mathrm{PGE}_{2}$ accumulated per $\mathrm{mg}$ of cellular protein in $10 \mathrm{~min}$ was calculated.

\section{Radioimmunoassay of prostaglandins}

$\mathrm{PGE}_{2}, \mathrm{PGF}_{2 \alpha}$ and PGFM in the media were measured by radioimmunoassays using previously described antibodies

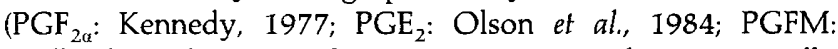
Guilbault et al., 1994). The assays were carried out essentially as described by Kennedy (1979). However, because prostaglandins were measured directly in the media without extraction, the same volume of media as contained in the samples was added to the standards. Preliminary work showed that the concentrations of prostaglandins measured by this method were not significantly different from those determined after extraction. Intra- and interassay coefficients of variation were less than $8 \%$ and $12 \%$, respectively. $\alpha$-Amanitin, cycloheximide, arachidonic acid and dexamethasone, at the same concentrations present in the samples, did not affect the radioimmunoassay for $\mathrm{PGE}_{2}$.

\section{Statistical analyses}

Heterogeneity of variance was removed by logarithmically transforming all data before statistical analysis. Analysis of 


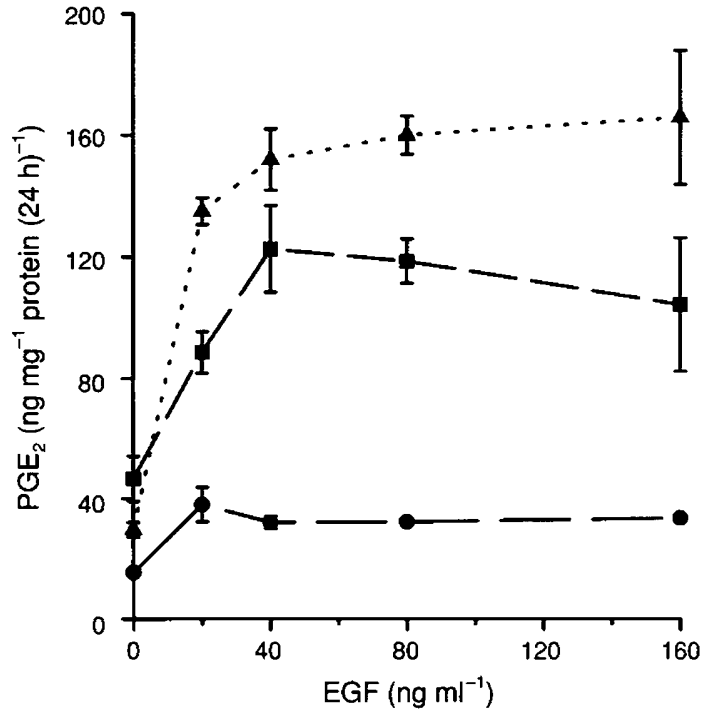

Fig. 2. The effect of exposure of rat endometrial stromal cells to various concentrations of epidermal growth factor (EGF, 0-160 ng $\mathrm{ml}^{-1}$ ) for $24 \mathrm{~h}$ on prostaglandin $\mathrm{E}_{2}\left(\mathrm{PGE}_{2}\right)$ accumulation in the medium on days $1(\bullet), 2(\square)$ or $3(\Lambda)$ of culture. Each point represents the mean $\pm \operatorname{SEM}(n=4-5)$.

variance was used to determine treatment effects. When a significant $(P<0.05)$ interaction was detected, Duncan's multiple range test was used for group comparisons. All statistical analyses were carried out using SAS statistical software (Cary, NC).

The data are presented as means $\pm \operatorname{SEM}(n=4-6)$ from single experiments. Each experiment was performed at least twice on separate cell preparations. Since prostaglandin concentrations in treatment groups varied between experiments, the data from separate cell preparations were not pooled. However, in all experiments, treatment effects were similar.

\section{Results}

\section{Concentration-response relationship of $E G F$}

After the differential attachment period, cells were cultured for 0,24 or $48 \mathrm{~h}$ before the addition of various concentrations of EGF for $24 \mathrm{~h}$ (day 1,2 or 3, respectively). $\mathrm{PGE}_{2}$ accumulation was significantly $(P<0.005)$ increased at all concentrations used (Fig. 2). During maximal stimulation ( $\geq 20-40 \mathrm{ng} \mathrm{ml}^{-1}$ ), EGF caused approximately 2-, 2.5-, and 5-fold increases in $\mathrm{PGE}_{2}$ accumulation on days 1,2 and 3 of culture, respectively. Because a greater response was consistently obtained on day 3 compared with days 1 or 2 , the remaining experiments were performed on day 3 of culture.

In a separate experiment, basal accumulations of $\mathrm{PGE}_{2}$, $\mathrm{PGF}_{2 \alpha}$ and PGFM on day 3 of culture were $60.7 \pm 9.2$, $26.2 \pm 0.6$ and $14.4 \pm 1.8 \mathrm{ng} \mathrm{mg}^{-1}(24 \mathrm{~h})^{-1}(n=5)$, respectively. Exposure to EGF ( $40 \mathrm{ng} \mathrm{ml}^{-1}$ ) increased $\mathrm{PGE}_{2}, \mathrm{PGF}_{2 a}$ and PGFM accumulation to $418 \pm 56,88.0 \pm 7.4$ and $59.8 \pm 6.1$, respectively. Analysis of variance of the logtransformed data revealed a significant $(P<0.01)$ interaction between prostaglandin type and EGF treatment, brought about

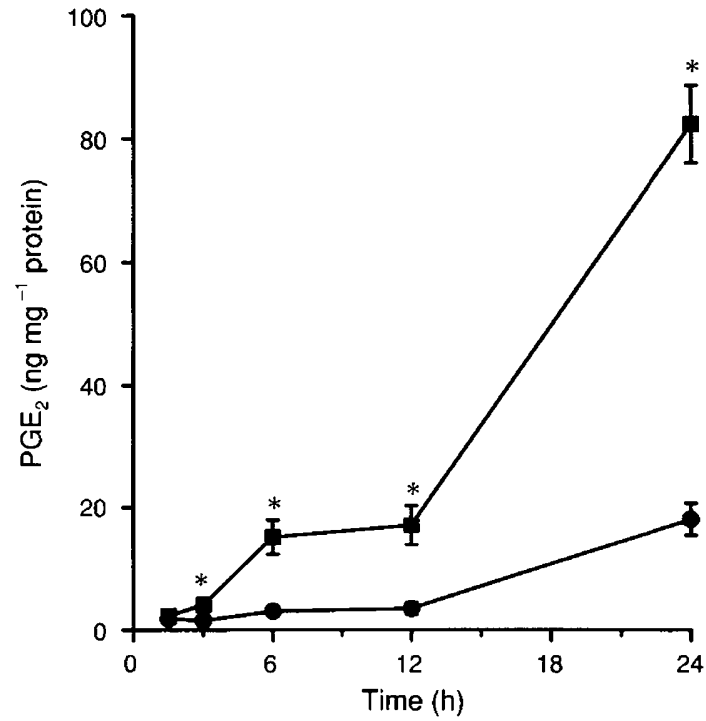

Fig. 3. The effect of exposure of rat endometrial stromal cells to medium in the presence ( $\boldsymbol{\square}$ ) or absence ( $\bullet$ ) of epidermal growth factor (EGF) $\left(40 \mathrm{ng} \mathrm{ml}^{-1}\right)$ for various periods $(1.5-24 \mathrm{~h})$ on prostaglandin $E_{2}$ $\left(\mathrm{PGE}_{2}\right)$ accumulation in the medium on day 3 of culture. Each point represents the mean \pm SEM $(n=4-5)$. *Significant differences between control and EGF-treated cells $(P<0.05)$.

because the increase in $\mathrm{PGE}_{2}$ in response to EGF was greater than those of $\mathrm{PGF}_{2 \alpha}$ and PGFM, which were similar. $\mathrm{PGE}_{2}$ accumulation was significantly greater $(P<0.01)$ than that of $\mathrm{PGF}_{2 \alpha}$ and PGFM for both control and EGF-treated cells.

\section{Time-course of the effect of EGF on $P G E_{2}$ accumulation and cyclooxygenase activity}

Stromal cells were incubated with or without EGF $40 \mathrm{ng}$ $\mathrm{ml}^{-1}$ ) for $1.5,3,6,12$, or $24 \mathrm{~h}$ on day 3 of culture, and $\mathrm{PGE}_{2}$ accumulation in the media and cyclooxygenase activity in the cells were measured. There was a significant increase $(P<0.001)$ in $P G_{2}$ accumulation in the media after 3 (2.7-fold), 6 (5-fold), 12 (5-fold) and 24 (4.6-fold) h exposure of the cells to EGF, compared with control cells, but not after $1.5 \mathrm{~h}$ exposure (Fig. 3). Similarly, there was a significant increase $(P<0.001)$ in cyclooxygenase activity in the cells after 3 (2.5-fold), 6 (3-fold), 12 (4.3-fold) and 24 (4.5-fold) h exposure to EGF, compared with control cells, but not after $1.5 \mathrm{~h}$ exposure (Fig. 4).

Effects of inhibitors of protein and $m R N A$ synthesis on $P G E_{2}$ accumulation and cyclooxygenase activity

Cycloheximide $\left(0.5 \mu \mathrm{g} \mathrm{ml}^{-1}\right)$ and $\alpha$-amanitin $\left(2 \mu \mathrm{g} \mathrm{ml}^{-1}\right)$ were used to determine whether the EGF-induced increases in $\mathrm{PGE}_{2}$ accumulation and cyclooxygenase activity require protein synthesis and transcription, respectively. Cells were incubated with or without the inhibitor in the presence or absence of EGF ( $40 \mathrm{ng} \mathrm{ml}^{-1}$ ) on day 3 of culture. After exposure for $24 \mathrm{~h}, \mathrm{PGE}_{2}$ accumulation in the media and cyclooxygenase activity in the cells were measured. For both $\mathrm{PGE}_{2}$ accumulation and cyclooxygenase activity (Table 1 ), analysis of variance 


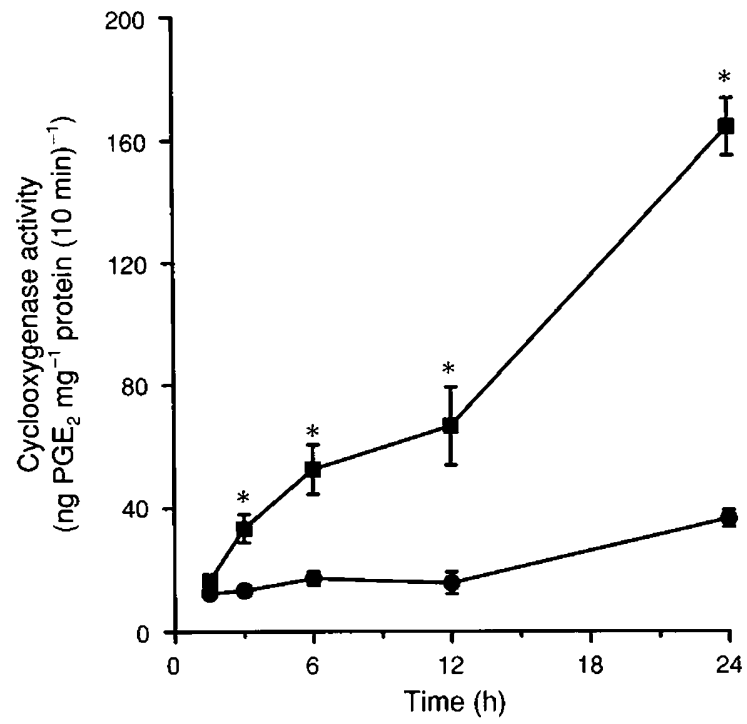

Fig. 4. The effect of exposure of rat endometrial stromal cells to medium containing ( $\boldsymbol{\square})$ and not containing $(\bullet)$ epidermal growth factor (EGF) $\left(40 \mathrm{ng} \mathrm{ml}^{-1}\right)$ for various periods (1.5-24 h) on cyclooxygenase activity on day 3 of culture. Each point represents the mean $\pm \operatorname{SEM}(n=4-5)$. *Significant differences between control and EGF-treated cells $(P<0.05)$

Table 1. The effects of exposure of rat endometrial stromal cells to cycloheximide $\left(0.5 \mu \mathrm{g} \mathrm{ml}^{-1}\right)$ or $\alpha$-amanitin $\left(2 \mu \mathrm{g} \mathrm{ml}^{-1}\right)$ for $24 \mathrm{~h}$ in the presence or absence of epidermal growth factor (EGF; $40 \mathrm{ng} \mathrm{ml}^{-1}$ ) on prostaglandin $\mathrm{E}_{2}\left(\mathrm{PGE}_{2}\right)$ accumulation in the medium and cyclooxygenase activity on day 3 of culture $^{\mathrm{a}}$

\begin{tabular}{lrc}
\hline & $\begin{array}{c}\mathrm{PGE}_{2} \\
\left(\mathrm{ng} \mathrm{mg} \mathrm{mg}^{-1}\right. \\
\text { protein }\left(24 \mathrm{~h}^{-1}\right)\end{array}$ & $\begin{array}{c}\text { Cyclooxygenase } \\
\text { activity } \\
\left(\mathrm{ng} \mathrm{PE}_{2} \mathrm{mg}^{-1} \text { protein }\right. \\
\left.(10 \mathrm{~min})^{-1}\right)\end{array}$ \\
\hline Control & $16.9 \pm 0.9^{\mathrm{b}}$ & $41.4 \pm 2.4^{\mathrm{b}}$ \\
EGF & $63.0 \pm 6.9^{\mathrm{c}}$ & $329.0 \pm 30.0^{\mathrm{c}}$ \\
Cyclohexamide & $9.6 \pm 0.6^{\mathrm{d}}$ & $27.4 \pm 4.9^{\mathrm{d}}$ \\
EGF and cyclohexamide & $16.8 \pm 1.3^{\mathrm{b}}$ & $48.6 \pm 4.2^{\mathrm{b}}$ \\
$\alpha$-Amanitin & $11.5 \pm 2.0^{\mathrm{d}}$ & $55.6 \pm 5.9^{\mathrm{b}}$ \\
EGF and $\alpha$-amanitin & $18.8 \pm 2.2^{\mathrm{b}}$ & $89.0 \pm 12.9^{\mathrm{e}}$ \\
\hline
\end{tabular}

${ }^{a}$ Values represent the means $\pm \operatorname{seM}\left\langle\mathrm{PGE}_{2}\right.$ accumulation, $n=4-5$; cyclooxygenase activity, $n=5$ ).

bcdeValues with the same letters within the same column are not significantly different $(P>0.05)$.

revealed significant $(P<0.02)$ interactions between the effects of cycloheximide or $\alpha$-amanitin and EGF. The stimulatory effect of EGF, when added alone, was greatly reduced in the presence of either cycloheximide or $\alpha$-amanitin. In the absence of EGF, cycloheximide significantly decreased $(P<0.05) \mathrm{PGE}_{2}$ accumulation and cyclooxygenase activity to values below those of controls. In the presence of $\alpha$-amanitin, basal $\mathrm{PGE}_{2}$ accumulation was significantly reduced $(P<0.05)$ compared with control values.
Table 2. The effect of exposure of rat endometrial stromal cells to dexamethasone $\left(5 \mu \mathrm{mol} \mathrm{l}{ }^{-1}\right)$ for $24 \mathrm{~h}$ in the presence or absence of epidermal growth factor (EGF; $40 \mathrm{ng} \mathrm{ml}^{-1}$ ) on prostaglandin $\mathrm{E}_{2}\left(\mathrm{PGE}_{2}\right)$ accumulation in the medium and cyclooxygenase activity on day 3 of culture ${ }^{a}$

\begin{tabular}{|c|c|c|}
\hline Treatment & $\begin{array}{c}\text { PGE }_{2} \\
\text { (ng mg } \\
\text { protein }\left(24 \mathrm{~h}^{-1} \text { ) }\right.\end{array}$ & $\begin{array}{c}\text { Cyclooxygenase } \\
\text { activity } \\
\text { (ng } \mathrm{PGE}_{2} \mathrm{mg}^{-1} \text { protein } \\
\left.(10 \mathrm{~min})^{-1}\right)\end{array}$ \\
\hline Control & $43.3 \pm 4.5^{\mathrm{b}}$ & $62.1 \pm 6.5^{b}$ \\
\hline $\mathrm{EGF}$ & $342.0 \pm 43.0^{c}$ & $266.0 \pm 21.0^{\mathrm{c}}$ \\
\hline Dexamethasone & $9.93 \pm 1.4^{\mathrm{d}}$ & $38.2 \pm 11.0^{\mathrm{d}}$ \\
\hline EGF and dexamethasone & $19.1 \pm 2.4^{\mathrm{d}}$ & $90.6 \pm 9.5^{b}$ \\
\hline
\end{tabular}

${ }^{\text {aV }}$ alues represent the means \pm SEM $(n=5-6)$.

bed $V$ alues with the same letters within a column are not significantly different $\langle P>0.05)$.

Effect of dexamethasone on PGE accumulation and cyclooxygenase activity

Cells were incubated with or without dexamethasone $\left(5 \mu \mathrm{mol} \mathrm{l}^{-1}\right)$ in the presence or absence of EGF $\left(40 \mathrm{ng} \mathrm{ml}^{-1}\right)$ for $24 \mathrm{~h}$ on day 3 of culture. For both $\mathrm{PGE}_{2}$ accumulation and cyclooxygenase activity (Table 2), analyses of variance indicated significant interactions $(P<0.0001)$ between the effects of EGF and dexamethasone. Dexamethasone alone reduced $\mathrm{PGE}_{2}$ accumulation and cyclooxygenase activity compared with controls, and greatly reduced the stimulatory effects of EGF on both responses.

\section{Discussion}

The study reported here showed that EGF stimulates the accumulation of $\mathrm{PGE}_{2}$ and $\mathrm{PGF}_{2 a}$ in the media of cultured endometrial stromal cells isolated from rat uteri sensitized for the decidual cell reaction. In mammalian cells, prostaglandins of the 2-series are synthesized from arachidonic acid through the sequential actions of phospholipases, cyclooxygenase and several prostaglandin synthases (Smith et al., 1991). Therefore, in the present study, EGF may have stimulated prostaglandin production in the stromal cells by increasing the activity of one or more of these enzymes. The mobilization of arachidonic acid from membrane lipids through the activation of phospholipases has been suggested to be the rate-limiting step of prostaglandin production in mammalian cells (Lapetina, 1982). Since the addition of exogenous arachidonic acid caused an increase in the accumulation of $\mathrm{PGE}_{2}$ in the media of stimulated and nonstimulated cells, it is apparent that the mobilization of arachidonic acid is a rate-limiting step in the synthesis of prostaglandins by cultured endometrial stromal cells. However, the extent of net prostaglandin production in several nonuterine cell types depends on the level of expression of cyclooxygenase (DeWitt, 1991). The level of cyclooxygenase expression is important because it is inactivated during catalysis (Egan et al., 1976) and thus must be replaced to sustain prostaglandin production. In this study, EGF caused a 
time-dependent increase in cyclooxygenase activity, as indicated by an increase in $\mathrm{PGE}_{2}$ accumulation in the media in the presence of saturating amounts of arachidonic acid in $10 \mathrm{~min}$. It is notable that studies on other cell types have shown that EGF can also stimulate cyclooxygenase activity (Yokota et al., 1986; Pash and Bailey, 1988). A time-dependent increase in $\mathrm{PGE}_{2}$ accumulation in the media of the endometrial stromal cells was paralleled by an increase in cyclooxygenase activity. One interpretation of the results of the study reported here is that EGF may cause an increase in prostaglandin accumulation in the media of cultured endometrial stromal cells through mechanisms that include an increase in cyclooxygenase activity. Alternatively, the increase in prostaglandin accumulation brought about by EGF may be due to an increase in phospholipase activity, and a basal amount of cyclooxygenase activity may be sufficient.

Since cyclooxygenase is inactivated during catalysis, an increase in its activity in the endometrial stromal cells was probably the result of increased expression of the gene encoding cyclooxygenase. In this study, the EGF-induced increase in both $\mathrm{PGE}_{2}$ accumulation and cyclooxygenase activity were both sensitive to $\alpha$-amanitin and cycloheximide, thus showing their dependence on transcription and translation. Two isozymes of cyclooxygenase, cyclooxygenase- $I$ and cyclooxygenase-2, have been reported in rats (Feng et al., 1993), mice (DeWitt et al., 1991; Kujubu et al., 1991) and humans (Hla and Neilson, 1992; Takahashi et al., 1992). Although the abundance of mRNA of both cyclooxygenase- 1 and cyclooxygenase- 2 can be increased by agents such as serum, phorbol esters and cAMP, those of cyclooxygenase- 1 are increased to a lesser extent, or not at all (DeWitt et al., 1991; Simmons et al., 1991; O'Banion et al., 1992; Herschman et al., 1993). In addition, expression of the gene encoding cyclooxygenase-2, but not cyclooxygenase- 1 , is negatively regulated by glucocorticoids (O'Banion et al., 1992). It has been shown that EGF can cause a specific increase in the expression of cyclooxygenase-2 in 3T3 cells (Kujubu et al,, 1991). However, further studies are required to determine the effect of EGF on expression of genes encoding cyclooxygenase- $I$ and cyclooxygenase- 2 in endometrial stromal cells.

$\mathrm{PGE}_{2}$ and $\mathrm{PGF}_{2 \alpha}$ are synthesized from $\mathrm{PGH}_{2}$ through the actions of synthases (Smith et al., 1991). Therefore, the observed increases in the accumulation of these biologically active prostaglandins by the cultured endometrial stromal cells in response to EGF may involve the modulation of the activity of these synthases. Since EGF stimulated a greater increase in $\mathrm{PGE}_{2}$ accumulation than $\mathrm{PGF}_{2 \alpha^{\prime}}$ it is possible that EGF preferentially stimulated $\mathrm{PGE}_{2}$ synthase over $\mathrm{PGF}_{2 a}$ synthase. However, further studies are required to determine whether EGF exerts such an effect.

The increases in $\mathrm{PGE}_{2}$ and $\mathrm{PGF}_{2 \alpha}$ accumulation in the media of the cultured endometrial stromal cells may be brought about by an EGF-induced decrease in prostaglandin catabolism. PGFM and PGEM are formed from $\mathrm{PGF}_{2 \alpha}$ and $\mathrm{PGE}_{2}$ by the sequential actions of two key enzymes of prostaglandin catabolism, prostaglandin dehydrogenase and $\Delta 13$-14-reductase (Samuelsson et al., 1971). Since PGFM is the more stable metabolite, the effect of EGF on PGFM accumulation in the media of cultured endometrial stromal cells was measured. The presence of PGFM in the media of the uterine stromal cells detected in this study strongly suggests that the stromal cells contain these enzymes. Furthermore, an increase in $\mathrm{PGF}_{2 a}$ accumulation in response to EGF was accompanied by a similar increase in PGFM accumulation, implying that EGF does not cause a decrease in prostaglandin catabolism in the endometrial stromal cells. If this is the case, then the amount of prostaglandin accumulation measured in the study reported here provides an appropriate index of prostaglandin production.

Regulation of endometrial stromal cell prostaglandin biosynthesis by factors other than EGF have been described. For example, interleukin $I$ can induce prostaglandin secretion by endometrial stromal cells isolated from mice (Jacobs and Carson, 1993). In addition, oestrogen and progesterone increase prostaglandin production by the uteri of ovariectomized rats (Castracane and Jordan, 1975). The relationship between steroids, interleukin 1 and EGF-receptor ligands in the regulation of endometrial prostaglandin production during implantation is unknown; the action of steroids in the uterus may be mediated by locally produced endometrial growth factors (Huet-Hudson et al., 1990a,b; Nelson et al., 1992). Therefore, it is likely that a complex network of signals is responsible for modulating prostaglandin production in the endometrium during implantation.

In summary, the present study shows that EGF stimulates prostaglandin production and cyclooxygenase activity in endometrial stromal cells isolated from rat uteri sensitized for the decidual cell reaction. These effects were inhibited by dexamethasone and inhibitors of transcription and translation. Therefore, this study provides evidence that EGF causes an increase in the expression of cyclooxygenase in endometrial stromal cells.

This work was supported by the Medical Research Council of Canada grant MA-10414.

\section{References}

Bossert NL, Nelson KC, Ross KA, Takahashi T and McLachlan JA (1990) Epidermal growth factor binding and receptor distribution in the mouse reproductive tract during development Developmental Biology 142 75-85

Brown MJ, Zogg JL, Schultz GS and Hilton FK (1989) Increased binding of epidermal growth factor at peri-implantation sites in mouse uteri Endocrinology $124 \quad 2882-2888$

Castracane VD and Jordan VC (1975) The effect of estrogen and progesterone on uterine prostaglandin biosynthesis in the ovariectomized rat Biology of Reproduction 13 587-596

Chakraborty C, Tawfik OW and Dey SK (1988) Epidermal growth factor binding in the rat uterus during the peri-implantation period Biochemical and Biophysical Research Communications 153 564-569

Das SK, Wang X-N, Paria BC, Damm D, Abraham JA, Klagsburn M, Andrews GK and Dey SK (1994a) Heparin-binding EGF-like growth factor gene is induced in the mouse uterus temporally by the blastocyst solely at the site of its apposition: a possible ligand for interaction with blastocyst EGF-receptor in implantation Development 120 1071-1083

Das SK, Tsukamura H, Paria BC, Andrews GK and Dey SK (1994b) Differential expression of epidermal growth factor receptor (EGF-R) gene and regulation of EGF-R bioactivity by progesterone and estrogen in the adult mouse uterus Endocrinology 134 971-98I

DeWitt DL (1991) Prostaglandin endoperoxide synthase: regulation of enzyme expression Biochimica et Biophysica Acta 1083 121-134

DeWitt DL, Kraemer SA and Meade EA (1991) Serum and superinduction of PGG/H synthase mRNA levels in 3T3 fibroblasts. In Prostaglandins and Related Compounds $I I$ pp 75-90 Ed. B. Samuelsson. Raven Press, New York 
Egan RW, Paxton J and Kuehl FA (1976) Mechanism for irreversible selfdeactivation of prostaglandin synthase Journal of Biological Chemistry $\mathbf{2 5 1}$ $7329-7335$

Feng L, Sun W, Xia X, Tang WW, Chanmugam P, Soyoola E, Wilson CB and Hwang D (1993) Cloning of two isoforms of rat cyclooxygenase: differential regulation of their expression Archives of Biochemistry and Biophysics $\mathbf{3 0 7}$ 361-368

Guilbault LA, Thatcher WW, Drost M and Hopkins SM (1984) Source of F series prostaglandins during the early postpartum period in cattle Biology of Reproduction $31879-887$

Herschman HR, Fletcher BS and Kujubu DA (1993) TIS10, a mitogen-inducible glucocorticoid-inhibited gene that encodes a second prostaglandin synthasef cyclooxygenase enzyme Journal of Lipid Mediators 5 89-99

Hla T and Neilson K (1992) Human cyclooxygenase-2 cDNA Proceedings of the National Academy of Sciences USA $897384-7388$

Huet-Hudson YM, Andrews GK and Dey SK (1990a) Epidermal growth factor and pregnancy in the mouse. In Early Embryo Development and Paracrine Relationships pp 125-136 Eds S Heyner and LM Wiley. Wiley-Leiss, New York

Huet-Hudson YM, Chakraborty C, De SK, Suzuki Y, Andrews GK and Dey SK (1990b) Estrogen regulates the synthesis of epidermal growth factor in mouse uterine epithelial cells Molecular Endocrinology 4 510-523

Jacobs AL and Carson DD (1993) Uterine epithelial cell secretion of interleukin- $1 \alpha$ induces prostaglandin $\mathrm{E}_{2}\left(\mathrm{PGE}_{2}\right)$ and $\mathrm{F}_{2 \alpha}$ secretion by uterine stromal cells in vitro Endocrinology 132 300-308

Johnson DC and Chatterjee S (1993a) Epidermal growth factor (EGF) replaces estradiol for the initiation of implantation in the hypophysectomized rat Placenta 14 429-438

Johnson DC and Chatterjee S (1993b) Embryo implantation in the rat uterus induced by epidermal growth factor Journal of Reproduction and Fertility 99 $557-559$

Kennedy TG (1977) Evidence for a role for prostaglandins in the initiation of blastocyst implantation in the rat Biology of Reproduction 16 286-291

Kennedy TG (1979) Prostaglandins and increased endometrial vascular permeability resulting from the application of an artificial stimulus to the uterus of the rat sensitized for the decidual cell reaction Biology of Reproduction 20 560-566

Kennedy TG (1990) Eicosanoids and blastocyst implantation. In Eicosanoids and Reproduction pp 123-138 Ed. MD Mitchell. CRC Press, Boca Raton

Kujubu DA, Fletcher BS, Varnum BC, Lim RW and Herschman HR (1991) TIS10 a phorbol ester tumor promotor-inducible mRNA from Swiss-3T3 cells, encodes a novel prostaglandin synthase/cyclooxygenase homologue journal of Biological Chemistry $26612866-12872$

Lapetina EG (1982) Regulation of arachidonic acid production: role of phospholipase $C$ and $A_{2}$ Trends in Pharmacological Sciences 3 115-118

Lee SH, Soyoola E, Chanmugam P, Hart S, Sun W, Zhong H, Liou S, Simmons D and Hwang D (1992) Selective expression of mitogen-inducible cyclooxygenase in macrophages stimulated with lipopolysaccharide Journal of Biological Chemistry $26725934-25938$

Lin T-H, Mukku VR, Verner G, Kirkland JL and Stancel GM (1988) Autoradiographic localization of epidermal growth factor receptors to all major uterine cell types Biology of Reproduction 38 403-411
Lowry OH, Rosebrough NJ, Farr AL and Randall RJ (1951) Protein measurement with the folin phenol reagent Journal of Biological Chemistry 193 265-275

Nelson KG, Takahashi T, Lee DC, Luetteke NC, Bossert NL, Ross K, Eitzman BE and McLachlan JA (1992) Transforming growth factor- $\alpha$ is a potential mediator of estrogen action in the mouse uterus Endocrinology 131 16571664

O'Banion MK, Winn VD and Young DA (1992) cDNA cloning and functional activity of a glucocorticoid-regulated inflammatory cyclooxygenase Biochemistry 89 4888-4892

Olson DM, Lye SJ, Skinner K and Challis JRG (1984) Early changes in prostaglandin concentrations in ovine maternal and fetal plasma, amniotic fluid and from dispersed cells of intrauterine tissues before the onset of ACTH-induced pre-term labour Journal of Reproduction and Fertility 71 45-55

Paria BC, Das SK, Gupta A and Dey SK (1991) Reversal of indomethacininduced inhibition of implantation in the mouse by epidermal growth factor Prostaglandins 42 191-199

Paria BC, Das SK, Huet-Hudson YM and Dey SK (1994) Distribution of transforming growth factor $\alpha$ precursors in the mouse uterus during the periimplantation period and after steroid hormone treatments Biology of Reproduction 50 481-491

Pash JM and Bailey JM (1988) Inhibition by corticosteroids of epidermal growth factor-induced recovery of cyclooxygenase after aspirin activation FASEB Journal 2 2613-2618

Pollard JW (1990) Regulation of polypeptide growth factor synthesis and growth factor-related gene expression in the rat and mouse uterus before and after implantation Journal of Reproduction and Fertility 88 721-731

Prigent SA and Lemoine NR (1992) The type-1 (EGFR-related) family of growth factor receptors and their ligands Progress in Growth Hormone Research 4 $1-24$

Samuelsson B, Granstrom E, Green K and Hamburg M (1971) Metabolism of prostaglandins Annals of the New York Academy of Sciences 180 138-163

Simmons DL, Xie W, Chipman JG and Evett GE (1991) Multiple cyclooxygenases: cloning of mitogen-inducible forms. In Prostaglandins, Leukotrienes, Lipoxins, and PAF pp 67-78 Ed. JM Bailey. Plenum Publishers, New York

Smith SK (1991) The role of prostaglandins in implantation Baillière's Clinical Obstetrics and Gynaecology 5 73-94

Smith WL, Marnett LJ and DeWitt DL (1991) Prostaglandin and thromboxane biosynthesis Pharmacology and Therapeutics 49 153-179

Takahashi Y, Ueda N, Yoshimoto T, Yamamoto S, Yokoyama C, Miyata A, Tnabe T, Fuse I, Hattori A and Shibata A (1992) Immunoaffinity purification and cDNA cloning of human prostaglandin endoperoxide synthase (cyclooxygenase) Biochemical and Biophysical Research Communications 182 433-438

Tamada H, Das SK, Andrews GK and Dey SK (1991) Cell-type-specific expression of transforming growth factor- $\alpha$ in the mouse uterus during the peri-implantation period Biology of Reproduction 45 365-372

Yee GM and Kennedy TG (1991) Role of cyclic adenosine 3', $5^{\prime}$-monophosphate in mediating the effect of prostaglandin $\mathrm{E}_{2}$ on decidualization in vitro Biology of Reproduction 45 163-171

Yokota K, Kusaka M, Ohshima T, Yamamoto S, Kurihara N, Yoshino T and Kumegawa $M$ (1986) Stimulation of prostaglandin $E_{2}$ synthesis in cloned osteoblastic cells of mouse (MC3T3-E1) by epidermal growth factor Journal of Biological Chemistry 26115 410-15 415 